Arab Univ. J. Agric. Sci., Ain Shams Univ., Cairo, 13(3), 979 - 987, 2005

\title{
DISSIPATION OF MALATHION IN DILL AND CORIANDER PLANTS AND THEIR OILS
}

\section{[66]}

\author{
Mohamed M.T. Abd El-Rahman'; MayssounY. Zaki ${ }^{1}$ and Laila S. Hamouda ${ }^{2}$
}

\begin{abstract}
The insecticide malathion (57\% E.C.) was applied at the rate of 712.5 gm active ingredient per feddan on dill, Anethum graveolens L. and coriander, Corianderum sativum L. for controlling aphids infesting these plants. An analytical method, using gas chromatography equipped with flame photometric detector was used for detecting the insecticide residues. A field trial was conducted to determine the rate of dissipation of malathion in dill and coriander plants and in the resulting oil. Residue analysis showed that the initial deposits determined one hour after application were $35.81 \& 22.7 \mathrm{ppm}$ in dill and coriander plants, respectively. Rates of dissipation of malathion were $4.72,51.1,68.39,88.41$ and $93.49 \%$ in dill plants and were $13.61,43.22,66.78,86.26$ and $91.85 \%$ in coriander plants at $1,3,7,14$ and 21 days post treatment, respectively. The pesticide was decayed quite rapidly in and on dill and coriander plants and detectable residues (1.62 and $0.93 \mathrm{ppm})$ were observed in these plants 28 days after treatment. At harvest 46 days for coriander and 70 days for dill after application malathion was found at average levels of 0.78 $\mathrm{mg} / \mathrm{kg}$ and $0.54 \mathrm{mg} / \mathrm{kg}$ in dill and coriander dry seed, respectively. The volatile oil extracted from the seed by steam distillation process was contaminated with the insecticide at a higher levels than in the seed [about sevenfold in dill oil, $5.21 \mathrm{mg} / \mathrm{kg}$ and ninteenfold in coriander oil $10.16 \mathrm{mg} / \mathrm{kg}$ ]. This means that malathion had tendency to co-distill with the dill and coriander oil throughout steam distillation process.
\end{abstract}

Key words: Malathion, Insecticide, Residues, Medicinal plants, Volatile oil

\section{INTRODUCTION}

Malathion -(dimethoxy thiophosphoryl thio) succinate is one of the broad spectrum organophosphorus insecticide.
It was recommended by the Ministry of Agriculture for controlling medicinal plant pests in Egypt as in many other countries (Singh et al 1988; Al-Maz et al 1997; Ahmed et al 1998; Abd El-

1- National Organization for Drug Control and Research, Dokki, Cairo, Egypt

2- Entomology Department, Faculty of Science, Ain Shams University, Abbasiya Cairo, Egypt 
Arab Univ. J. Agric. Sci., Ain Shams Univ., Cairo, 13(3), 979 - 987, 2005

Rahman et al 2002 and More, et al 2003). Recently Kamel and Abd ElRahman (2005) evaluated the aphid infestations and its chemical control using malathion insecticide on dill and coriander plants.

Since the quality of these plants and its validity for use as drugs is greatly influenced by the contamination with pesticide residues. Many researcher have studied the persistence of organophosphorous pesticide residues in medicinal plants (Ennet, 1989; Al-Maze et al 1997; Zuin and Vilegas 2000;

Ahmed et al 2001; Abou-Arab and Donia, 2001 and Abd El-Rahman et al 2004). But little is known about tracing the fate of these chemicals in the active ingredient of these medicinal plants. Therefore, the present work is aimed to throw light on the disappearance dynamics of the insecticide malathion in both dill and coriander plant herbs and their oils.

\section{MATERIAL AND METHODS}

- The organophosphorous insecticide malathion with the following chemical structure and formula was used throughout the present investigation

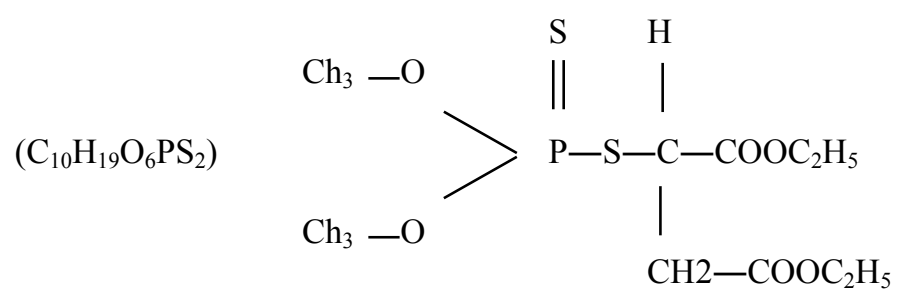

Diethyl mercaptosuccinate, S-ester with O, O-dimethyl phosphorodithioate

It was introduced by American Cyanamide Co. and recommended for aphids control in medicinal and aromatic plants by Ministry of Agriculture, Egypt.

- Field design and treatments
The experimental area was divided into 12 plots each of $25 \mathrm{~m}^{2}$. Each plot was separated from the other by one meter buffer zone. The experimental area was planted on the first of November 2003 at Giza governorate, six plots for dill plants and six plots for coriander plants. The cultivated area was received

1- National Organization for Drug Control and Research, Dokki, Cairo, Egypt

2- Entomology Department, Faculty of Science, Ain Shams University, Abbasiya Cairo, Egypt 
Arab Univ. J. Agric. Sci., Ain Shams Univ., Cairo, 13(3), 979 - 987, 2005

the normal agricultural practices of growing these plants. The insecticide malathion was applied on February 2nd, 2004 on dill and coriander plants in the separate plots. Two plots from each crop were left untreated as a control (check). A knapsack sprayer equipped with one nozzle was used for applying, the insecticide, malathion 57\% E.C. at the rate of 1.25 Liter per feddan as recommended rate which diluted with water to control aphid pests infesting these plants. Each plot received $1500 \mathrm{ml}$ of the insecticide solution. The control plots were sprayed with the appropriate quantity of water. About three hundred gram of samples were collected randomly, one hour after application and at $1,3,7,14,21$ and 28 days post treatment. Three replicates of each sample were kept in a deep freezer at $-20^{\circ} \mathrm{C}$ in polyethylene bags until used for residue analysis. At harvest time (70 days for dill and 46 days for coriander post malathion treatment), seed was collected from treated and untreated plots.

Twenty gram from these seeds were taken to produce dill and coriander essential oil by using steam distillation extractor according to the standard method of Egyptian Pharmacopeia, (1984). The mean percent of oil yields were 3.4 and $0.45 \mathrm{v} / \mathrm{w} \%$ for dill and coriander seeds, respectively. These seeds and their resulting essential oil plus plant samples, were subjected for residue analysis. The extraction was done with acetonitrile and partition with petroleum- ether 40-60. The petroleum-ether layer was dehydrated and cleaned-up using florisil column according to the Association Official Analytical Chemistry Method (AOAC, 1995).

\section{- Apparatus and Reagents}

A HP 5890 gas chromatography equipped with flame photometric and electron capture detectors was used. Standard laboratory glassware was used throughout the procedure. Analyticalgrade malathion was obtained from American Cyanamide Co.

\section{- Gas Chromatography}

A flame photometric detector operated with the 530-nm interference filter for phosphorus was used for the determination of malathion, the detector temperature was $270^{\circ} \mathrm{C}$ with gas flows to the detector of 140 , and 80 for hydrogen and air respectively. A CP-sil $19 \mathrm{CB}$ fused silica capillary column (30 mx 0.25 $\mathrm{mm}$ i.d. and $0.25 \mu \mathrm{m}$ film thickness) was used.

The GC injection temperature was $220^{\circ} \mathrm{C}$, and the initial oven temperature of the column was programmed from $100^{\circ} \mathrm{C}$ (hold for $2 \mathrm{~min}$ ) and raised at a rate of $10^{\circ} \mathrm{C} / \mathrm{min}$ up to $260^{\circ} \mathrm{C}$. The helium carrier gas flow was $1.5 \mathrm{ml} / \mathrm{min}$. According this method the retention time of malathion was 13.8 min. Fig. (1). Quantitation was carried out by peak height comparison of at least three closely matched pairs of

1- National Organization for Drug Control and Research, Dokki, Cairo, Egypt

2- Entomology Department, Faculty of Science, Ain Shams University, Abbasiya Cairo, Egypt 
sample and standard injections for malathion.

\section{- Recoveries in Fortified Samples}

Samples of dill and coriander herbs, seed and oil known to be free of the target analyte, were spiked with $5 \mathrm{ppm}$. The mean recovery rates for malathion were 93, 95 and $86 \%$ for dill samples and were 89,90 and $77 \%$ for coriander samples in herbs, seed and essential oil, respectively (Table, 1).

\section{RESULTS AND DISCUSSION}

Data in Table (2), indicated the amount of malathion residues in dill and coriander plants at specified days after application, on 2nd February, 2004 under winter condition of cool temperatures for control aphids pest infesting these plants. All results have been corrected for percentage recoveries.

Generally, a high initial residue deposits (one hour after application) were 35.81 and $22.7 \mathrm{ppm}$ in dill and coriander plants, respectively. These values were not greatly changed after one day of treatment, 34.12 and $19.61 \mathrm{ppm}$ in both plants indicating the dissipation rates of 4.72 and $13.61 \%$, respectively. Also, the obtained data are in expected pattern of rapid residue decline $(51.1 \%)$ in dill and 
Arab Univ. J. Agric. Sci., Ain Shams Univ., Cairo, 13(3), 979 - 987, 2005

1- National Organization for Drug Control and Research, Dokki, Cairo, Egypt

2- Entomology Department, Faculty of Science, Ain Shams University, Abbasiya Cairo, Egypt

(Received May 16, 2005)

(Accepted June 25, 2005) 
6

Mohamed Abd El-Rahman; Zaki and Hamouda

Table 1. Recovery of added malathion from untreated crops

\begin{tabular}{|ccccc|}
\hline Crops & $\begin{array}{c}\text { Fortified } \\
\text { samples }\end{array}$ & $\begin{array}{c}\text { No. of } \\
\text { recoveries }\end{array}$ & $\begin{array}{c}\text { Range of } \\
\text { recoveries } \\
\%\end{array}$ & $\begin{array}{c}\text { Average } \\
\text { recovery } \\
\%\end{array}$ \\
\hline Dill & herbs & 4 & $82-110$ & 93 \\
Anethum graveolens L. & & & & 95 \\
& seed & 3 & $90-98$ & 86 \\
Coriander & oil & 6 & $75-96$ & 89 \\
Corianderum sativum L. & herbs & 4 & $88-95$ & 90 \\
& & & & $71-101$ \\
& seed & 4 & $69-87$ & 77 \\
\hline
\end{tabular}

Table 2. Residues of malathion $(\mathrm{mg} / \mathrm{kg})$ in dill and coriander plants after foliar applications $^{\mathrm{a}}$

\begin{tabular}{|c|c|c|c|c|c|c|}
\hline \multirow[t]{3}{*}{$\begin{array}{l}\text { Days after } \\
\text { application }\end{array}$} & Resic & $\begin{array}{r}\mathrm{ppm}^{\mathbf{b}}, \\
\text { malat }\end{array}$ & $\begin{array}{l}\text { m appl } \\
\text { n on }\end{array}$ & tion of & \multirow{3}{*}{$\begin{array}{l}\begin{array}{l}\text { Relative } \\
\text { deposits }\end{array} \\
\left(\frac{\mathrm{R}_{2}}{\mathrm{R}_{1}}\right)\end{array}$} & \multirow{3}{*}{$\begin{array}{c}\text { Relative } \\
\text { dissipation } \\
\% \\
\left(\frac{\mathrm{L}_{2}}{\mathrm{~L}_{1}}\right)\end{array}$} \\
\hline & \multicolumn{2}{|c|}{ Dill plants } & \multicolumn{2}{|c|}{ Coriander plants } & & \\
\hline & $\begin{array}{l}\mathrm{ppm} \\
\left(\mathrm{R}_{1}\right)\end{array}$ & $\begin{array}{c}\% \text { loss } \\
\left(\mathrm{L}_{1}\right)\end{array}$ & $\begin{array}{l}\text { ppm } \\
\left(\mathrm{R}_{2}\right)\end{array}$ & $\begin{array}{c}\% \text { loss } \\
\left(\mathrm{L}_{2}\right)\end{array}$ & & \\
\hline $0^{c}$ & 35.81 & 0.00 & 22.7 & 0.00 & 0.63 & 0.00 \\
\hline 1 & 34.12 & 4.72 & 19.61 & 13.61 & 0.57 & 2.9 \\
\hline 3 & 17.51 & 51.1 & 12.89 & 43.22 & 0.74 & 0.85 \\
\hline 7 & 11.32 & 68.39 & 7.54 & 66.78 & 0.67 & 0.98 \\
\hline 14 & 4.15 & 88.41 & 3.12 & 86.26 & 0.75 & 0.98 \\
\hline 21 & 2.33 & 93.49 & 1.85 & 91.85 & 0.79 & 0.98 \\
\hline 28 & 1.62 & 95.48 & 0.93 & 95.9 & 0.57 & 1.00 \\
\hline $\mathrm{K}$ & 1.55 & & 1.36 & & & \\
\hline Slope & 0.15 & & 0.062 & & & \\
\hline T $1 / 2$ (days) & 2.1 & & 4.92 & & & \\
\hline
\end{tabular}

a) One application of malathion $57 \%$ ( $0.285 \%$ ai/feddan) by ground sprayer on February 2 nd, 2004. 
b) Figures are the average of three replicates and corrected for percentage recoveries.

c) Zero time $=$ samples were taken one hour after application (initial samples)

$\mathrm{K}=$ degradation rate.

$\mathrm{T} 1 / 2=$ residue half life in days. 
Arab Univ. J. Agric. Sci., Ain Shams Univ., Cairo, 13(3), 979 - 987, 2005

$(43.22 \%)$ loss in coriander plants within 3 days following treatments and less rapid decline there after. Malathion residues were $11.32,4.15$ and $2.33 \mathrm{mg} / \mathrm{kg}$ in dill plants and were $7.54,3.12$ and 1.85 $\mathrm{mg} / \mathrm{kg}$ in coriander plants after 7, 14, 21 days from applications, respectively. After 28 days from treatment the amounts of residues in dill and coriander plants were continued high and relatively constant (1.62 and 0.93 ppm showing 95.48 and $95.9 \%$ dissipation, respectively Table (2).

The established regression lines of the degraded malathion were obtained by plotting the logarithms of residues versus time. The resulting degradation rates of malathion residues (K-values) reached 1.55 and 1.36, while the residue half lives ( $\mathrm{t} 1 / 2$ ) were 2.1 and 4.92 days on dill and coriander plants, respectively. However, the residual behaviour of the insecticide on and in dill and coriander plants was varied depending on the nature and the weight of the treated surface. So relative deposit-residues to dill plants ranged from 0.57 to $0.79 \mathrm{ppm}$, but relative dissipation versus time was almost the same except after one day of application Table (2).

At harvest time the seeds of dill and coriander crops and their extracted oils by steam distillation process, were analyzed for the detection of malathion residues. Data in Table (3) indicated that the insecticide was in both seeds $(0.78$ and $0.54 \mathrm{ppm}$ ) and extracted oil content (5.21 and $10.16 \mathrm{ppm}$ ) of dill and coriander, respectively. The amount of malathion residues in dill and coriander distillate oils were correlated to that present in the seeds of both plants, $(\mathrm{r}=0.9$ and 0.45$)$. The averages of residue ratio were (6.7 ppm in dill and $18.93 \mathrm{ppm}$ in coriander crops) indicated that malathion had tendency to co-distill with the dill and coriander oil throughout steam distillation process.

Similar to the observation of Gould (1960) for dialdrin, aldrin, DDT and dibrom in peppermint oil, the relationship between volatility and steam distillability is expected. Gomaa et al (1984) reported that $25 \%$ of fenvalerate residues in the peppermint hay were distilled with the oil. The predominance of malathion residues in medicinal plants and its remedial products was discussed by Abou-Arab et al (1999), Abou Arab and Donia (2001), Ahmed et al (2001). Recently Abd El-Rahman et al (2004) recorded the highest mean levels of malathion $(1.17,1.63$ and $1.09 \mathrm{mg} / \mathrm{kg}$ ) in some remedial products. On the other hand, Almaz et al (1997) treated coriander, fennel and geranium plants in the field with malathion ( $57 \%$ EC) at the rate of $712.5 \mathrm{~g}$ active ingredient per feddan. They concluded that, the mature dry seed collected from coriander and fennel plants were devoid of any detectable amounts of malathion and its metabolites and such seed could be marketed safely for human consumption. The same conclusion was also reported by Abd El-Rahman et al (2002). This

1- National Organization for Drug Control and Research, Dokki, Cairo, Egypt

2- Entomology Department, Faculty of Science, Ain Shams University, Abbasiya Cairo, Egypt 
9

Dissipation of malathion in dill and coriander

contradicting situation of finding is requires intensive studies in the future on the contamination with pesticides in medicinal plants and in their active ingredients.

\section{CONCLUSION}

Egyptian Organization for Standardization (EOS, 1991) specifies MRLs for malathion as $0.5 \mathrm{mg} / \mathrm{kg}$ in medicinal plants. However, all the levels of residues detected in dill and coriander crops including seeds and their extracted oils are exceeded than MRLs for malathion under 
Arab Univ. J. Agric. Sci., Ain Shams Univ., Cairo, 13(3), 979 - 987, 2005

Table 3. Level of malathion residues in dill and coriander seed and in its resulting oil at harvest time ${ }^{* * *}$

\begin{tabular}{|ccccccc|}
\hline No. of analysis & \multicolumn{5}{c|}{${ }^{* *}$ Malathion residues $\mathrm{mg} / \mathrm{kg}$} \\
\hline & \multicolumn{3}{c}{ In dill crop } & \multicolumn{3}{c|}{ In coriander crop } \\
\hline & Seed & Oil $^{*}$ & $\begin{array}{c}\text { Residue } \\
\text { ratio }\end{array}$ & Seed & Oil $^{*}$ & $\begin{array}{c}\text { Residue } \\
\text { ratio }\end{array}$ \\
\hline 1 & 0.78 & 5.24 & 6.72 & 0.54 & 9.14 & 16.93 \\
2 & 0.91 & 5.78 & 6.35 & 0.46 & 9.82 & 21.35 \\
3 & 0.63 & 4.35 & 6.90 & 0.57 & 11.5 & 20.18 \\
4 & 0.8 & 5.47 & 6.84 & 0.59 & 10.18 & 17.25 \\
Average & 0.78 & 5.21 & 6.7 & 0.54 & 10.16 & 18.93 \\
\hline Correlation coefficient (r) & \multicolumn{7}{c}{0.9} & & & 0.45 \\
\hline
\end{tabular}

* Duration time of steam distillation was two hour.

** MRLs mg/kg (0.5) for malathion according to the Egyptian Organization for Standardization (EOS) 1991.

*** Dill and coriander crops harvested on April 13, and March 20, 2004, respectively.

Residue ratio $=\frac{\mathrm{ppm} \text { in oil }}{\mathrm{ppm} \text { in seed }}$

the prevailed experimental conditions. On the basis of these results, malathion, contamination in the volatile oils of dill and coriander plants, must pose a significant risk to consumers, and quality control must be required for the distilled oil products.

\section{REFERENCES}

Abdel-Rahman, H.A.; Z.H. Zidan; F.R. Ali and S.E. Havez (2002). Population density of two aphid species and their control by conventional and bioinsecticides on certain medicinal plants. J. Egypt. Acad. Sci. Environ. Develop. (A. Entomology), 2(1): 67-94.

Abdel-Rahman, M.M.T.; S.M. Fahmy and M.Y. Zaki (2004). Monitoring of pesticide residues in some herbal preparations and phytomedicines. $\boldsymbol{J}$. Drug Res. Egypt, 25 (1-2): 166-169. Abou-Arab, A.A.K. and M.A.A. Donia (2001). Pesticide residues in some Egyptian spices and medicinal plants as

1- National Organization for Drug Control and Research, Dokki, Cairo, Egypt

2- Entomology Department, Faculty of Science, Ain Shams University, Abbasiya Cairo, Egypt 
Arab Univ. J. Agric. Sci., Ain Shams Univ., Cairo, 13(3), 979 - 987, 2005

affected by processing. Food Chem., 72: 439-445.

Abou-Arab, A.A.K.; K.M. Soliman;

M.E. El-Tantawy; B.R. Ismail and K. Naguib (1999). Quantity estimation of some contaminants in commonly used medicinal plants in the Egyptian market.

Food Chem., 67: 357-363.

Ahmed, M.T.; N. Loutfy and Y. Yousef (2001). Contamination of medicinal herbs with organophosphorus insecticides. Bull. Environ. Contam. Toxicol., 66: 421426.

Ahmed, M.T.; S.M. Ismail and Y.Y. Mosleh (1998). Determination of malathion residues in some medicinal plants by liquid chromatography with gas chromatography mass spectroscopic confirmation, J. Assoc. Off. Anal Chem., 81: 1026-1029.

Almaz, M.M.; S.M. Fahmy and S. Dogheim (1997). Residues of malathion on and in certain plants of medical importance Egypt J. Agric. Res., 75(1): 157-163.

AOAC (1995). Official methods of analysis pesticide and industrial chemical residues $16^{\text {th }}$ Ed pp. 1-78, Washington

D.C.

Egyptian Pharmacopeia (1984). Determination of volatile oils, Ministry of Health, Cairo, Egypt, pp. 31-34.

Ennet, D. (1989). Contaminants in plant drugs. Pharmazie, 44: 383-386.

EOS. (Egyptian Organization for Standardization and Quality Control (1991). Maximum limits for pesticide residues on medicinal and aromatic plants. Sep. 1991, pp. 1-4. 
Gomaa E.A.A.; M.M.T. Abd ElRahman and A.E. Omar (1984). Decay dynamics of fenvalerate in Mentha Piperita L. and in the resulting oil. $\boldsymbol{J}$. Drug Res. Egypt, 15(1-2): 113-119. Gould, G.E. (1960). Problems in the control of mint insects. J. Econ. Ent., 53: 526-531.

Kamel, K.E. and M.M.T. Abd ElRahman (2005). Incidence and chemical control of aphids on dill and coriander plants. J. Egypt. Acad. Sci. Environ. Develop. (A. Entomology), 6(1):97-107. More, P.S.; B.D. Desai; V.N. Jalagaonkar and R.S. Mule (2003).
Record of pests infesting arecanut Areca catechu L. and their seasonal incidence. Ind. J. Arecanut-Spices and Medicinal Plants, 5(1): 5-8.

Singh, D.; A.K. Tripathi and S.M. Rao (1988). Phenology and chemical control of aphid Myzus persicae on henbane (Hyoscyamus niger and H. muticus Ind. J. Agric. Sci., 58: 292-296.

Zuin, V.G. and J.H.Y. Vilegas (2000). Pesticide residues in medicinal plants and phytomedicines. Phytotherapy Research, 14: 73-88. 
Arab Univ. J. Agric. Sci., Ain Shams Univ., Cairo, 13(3), 979 - 987, 2005

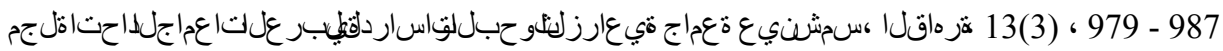
، 2005

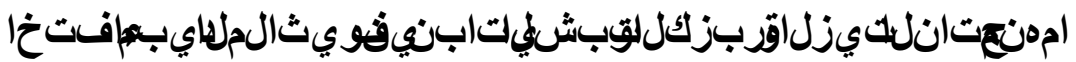

]66[

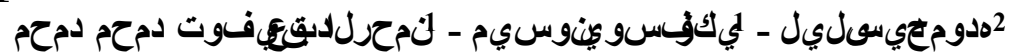

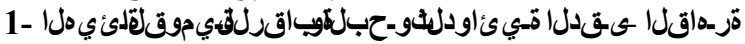

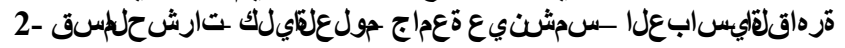

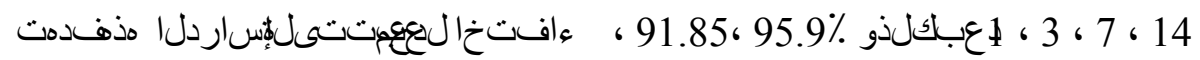

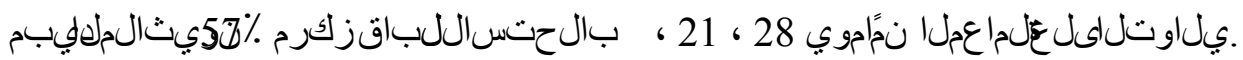

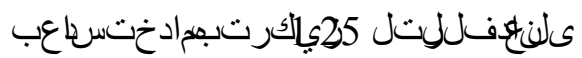

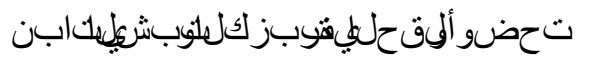

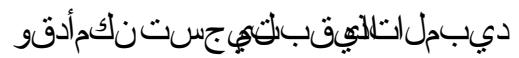

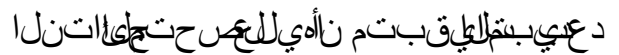

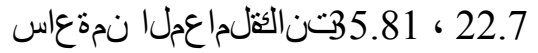

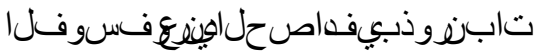

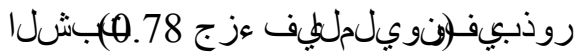

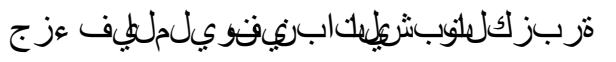

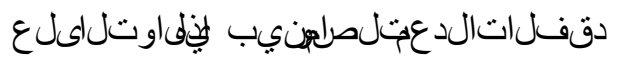

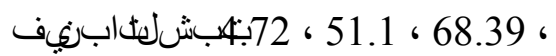

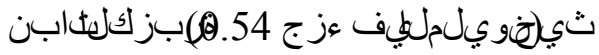

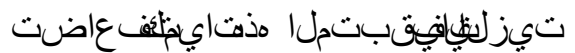

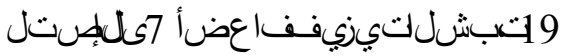
تابزيف

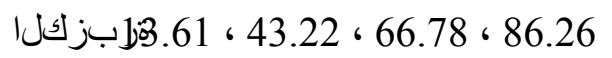

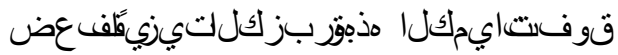

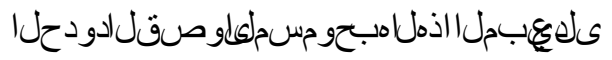

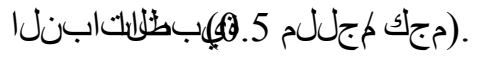

ديمحللباع عدنهناديز د:ألميك حت

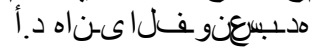

1- National Organization for Drug Control and Research, Dokki, Cairo, Egypt

2- Entomology Department, Faculty of Science, Ain Shams University, Abbasiya Cairo, Egypt 